\title{
PENGGUNAAN APLIKASI MACROMEDIA FLASH SEBAGAI MEDIA PEMBELAJARAN DALAM MODEL PEMBELAJARAN POE2WE UNTUK MENINGKATKAN PEMAHAMAN SISWA DALAM MATA PELAJARAN FISIKA
}

\author{
Hamzah Saepul Anwar ${ }^{*}$, Nana ${ }^{2}$ \\ ${ }^{1}$ Mahasiswa Program Studi Pendidikan Fisika Universitas Siliwangi \\ ${ }^{2}$ Dosen Program Studi Pendidikan Fisika Universitas Siliwangi \\ *E-mail: hamzahsa19@gmail.com
}

\begin{abstract}
Abstrak: penggunaan aplikasi digital pada pembelajaran mata pelajaran fisika menggunakan model pembelajaran POE2WE bertujuan untuk (1) menciptakan pembelajaran lebih mudah dan menyenangkan. (2) menciptakan proses pembelajaran lebih interaktif dan inovatif. (3) meningkatkan pemahaman siswa dalam mempelajari meteri fisika. Metode penilitian yang digunakan adalah metode literasi (studi pustaka). Apliaksi digital merupakan media yang patut dicoba dan digunakan dengan baik agar suatu media berbasis digital tidak disalahgunakan. Macromedia Flash adalah program yang dikeluarkan adobe untuk mendesain suatu Animasi yang menarik bagi semua kalangan khususnya anak muda. Maka memanfaatkan suatu media untuk dijadikan media pembelajaran akan lebih menguntungkan dibandingkan dengan tidak menggunakan media pembelajaran sama sekali.
\end{abstract}

Kata kunci: POE2WE, Macromedia Flash

\section{PENDAHULUAN}

Pada era sekarang dikenal dengan era digital atau revolusi industri abad 21. Pada era ini kita dituntut untuk memanfaatkan teknologi secara maksimal dalam berbagai aspek. Tak terkecuali dalam dunia pendidikan. Perkembangan teknologi berperan penting dalam perkembangan pembelajaran saat ini karena tanpa teknologi dewasa ini pembelajaran akan dianggap membosankan dan monoton. Teknologi pada hakikatnya adalah proses untuk mendapatkan nilai tambah dari produk yang dihasilkannya agar bermanfaat. Teknologi telah mempengaruhi dan mengubah manusia dalam kehidupannya sehari-hari, sehingga jika sekarang ini 'gagap teknologi' maka akan terlambat dalam menguasai informasi, dan akan tertinggal pula untuk memperoleh berbagai kesempatan maju. Informasi memiliki peran penting dan nyata, pada era masyarakat informasi (information society) atau masyarakat ilmu pengetahuan (Nana \& Endang Surahman, 2019).

Menurut Electronic Data Processing - EDP (Nana \& Endang Surahman, 2019) Komputer merupakan alat dan aplikasi teknologi berbasis informasi dan komunikasi yang dimanfaatkan sebagai perangkat utama untuk mengolah data menjadi informasi yang bermanfaat dengan memproses, menyajikan, dan mengelola informasi. Pengolahan data dengan komputer disebut dengan Pengolaan Data Elektronik.

Aplikasi Macromedia Flash Merupakan salah satu software plugin yang manfaatnya untuk membuka atau melihat gambar animasi, video juga game yang ada di dalam salah satu website system plugin (akhmad, 2014) ini sangat di sukai dan di buru para pecinta animasi di seluruh dunia tak terkecuali dalam pembelajaran fisika, karena dalam mempelajari suatu konsep fisika akan lebih mudah difahami dengan animasi bergerak secara nyata.

Software Macromedia Flash akan sangat penting bagi siswa yang sulit dalam memahami suatu konsep fisika karena keabstrakan materi tersebut. Media ini juga dapat meningkatkan skill siswa dalam memanfaatkan teknologi. Multimedia interaktif adalah media pembelajaran yang efektif untuk meningkatkan keterampilan mendengarkan kritis siswa (Vivit Febrian Danang Priandana, 2015) 


\section{METODE PENELITIAN}

Penelitian ini menggunakan metode literasi (studi pustaka) dengan cara mengkaji berbagai literatur yang berkaitan dengan penerapan model POE2WE, Media Pembelajaran dan Macromedia Flash.

\section{HASIL DAN PEMBAHASAN}

\subsection{Model POE2WE}

Model pembelajaran Prediction, Observation, Explanation, Elaboration, Write dan Evaluation (POE2WE) dikembangkan dari model pembelajaran POEW dan model pembelajaran Fisika dengan Pendekatan Konstruktivistik. Pengembangan ini dilakukan untuk sebagai penyempurnaan kedua model sebelumnya. Model POE2WE merupakan model pembelajaran yang dikembangkan untuk mengetahui pemahaman peserta didik mengenai suatu konsep dengan pendekatan konstruktivistik. Model ini membangun pengetahuan dengan urutan proses yaitu meramalkan atau memprediksi solusi dari permasalahan, melakukan eksperimen untuk membuktikan prediksi, kemudian menjelaskan hasil eksperimen yang diperoleh secara lisan maupun tertulis, membuat contoh penerapan dalam kehidupan seharihari, menuliskan hasil diskusi dan memuat evaluasi tentang pemahaman peserta didik baik secara lisan maupun tertulis. Menurut Nana (Nana, 2014).

Dalam model pembelajaran POE2WE siswa dilatih untuk menemukan sendiri konsep dari suatu materi yang sedang dipelajari karena dalam model tersebut siswa menganalisis sebuah pengalaman yang disajikan oleh pendidik. Penggetahuan siswa akan didapat melalui pengalaman sederhana yang menggiring mereka kepada kesimpulan yang mereka buat sendiri bukan melalui kesimpulan yang dibuat oleh oranglain ataupun guru. Dalam model pembelajaran ini juga siswa dapat merefleksikan apa yang telah mereka pelajari dengan mencatat kesimpulan apa yang mereka dapatkan dari materi yang telah mereka pelajari bersama.

Menurut Nana \& Endang, 2019. Penggabungan tahapan-tahapan pembelajaran model POEW dan model pembelajaran Fisika dengan Pendekatan Konstruktivistik maka dapat di susun langkah-langkah pembelajaran model POE2WE secara terinci sebagai berikut:

\section{a) Prediction}

Tahap prediction yaitu peserta didik membuat prediksi atau dugaan awal terhadap suatu permasalahan. Permasalahan yang ditemukan berasal dari pertanyaan dan gambar tentang materi yang disampaikan oleh guru yang ada di Lembar Kerja peserta didik (LKS)/bukupeserta didik sebelum peserta didik membuat prediksi. Pembuatan prediksi jawaban tahap Prediction pada model POEW identik dengan fase Engagenent pada pendekatan konstruktivistik. Guru mengajukan pertanyaan yang dapat mendorong peserta didik untuk dapat membuat prediksi atau jawaban sementara dari suatu permasalahan.

\section{b) Observation}

Tahap Observation yaitu untuk membuktikan prediksi yang telah di buat oleh pesera didik. Peserta didik diajak melakukan eksperimen berkaitan dengan masalah atau persoalan yang di temukan. Selanjutnya peserta didik mengamati apa yang terjadi, kemudian peserta didik menguji kebenaran dari dugaan sementara yang telah dibuat. Tahap Observation pada model POEW identik dengan fase Exploration pada pendekatan konstruktivistik.

c) Explanation

Tahap Explanation atau menjelaskan yaitu peserta didik memberikan penjelasan terhadap hasil eksperimen yang telah dilakukan. Penjelasan dari peserta didik dilakukan melalui diskusi dengan 
anggota kelompok kemudian tiap kelompok mempresentasikan hasil diskusinya di depan kelas. Jika prediksi yang di buat peserta didik ternyata terjadi di dalam eksperimen, maka guru membimbing peserta didik merangkum dan memberi penjelasan untuk menguatkan hasil eksperimen yang dilakukan. Namun jika prediksi peserta didik tidak terjadi dalam eksperimen, maka guru membantu peserta didik mencari penjelasan mengapa prediksi atau dugaannya tidak benar. Tahap explanation identik dengan fase explanation pada pendekatan konstuktivistik.

\section{d) Elaboration}

Tahap elaboration yaitu peserta didik membuat contoh atau menerapkan konsep dalam kehidupan sehari-hari. Tahap elaboration di ambil dari pendekatan konstruktivistik. Tahap ini guru medorong peserta didik untuk menerapkan konsep baru dalam situasi baru sehingga peserta didik lebih memahami konsep yang di ajarkan guru. Tahap ini pengembangan dari pendekatan konstruktivistik.

e) Write

Menulis dapat membantu peserta didik untuk mengekspresikan pengetahuan dan gagasan mereka. peserta didik menuliskan hasil diskusi dan menjawab pertanyaan yang ada pada LKS. Selain itu pada tahap write ini, peserta didik membuat kesimpulan dan laporan dari hasil eksperimen. Tahap ini merupakan pengembangan dari model TTW.

f) Evaluation

Tahap Evaluation yaitu evaluasi terhadap pengetahuan, keterampilan dan perubahan proses berfikir peserta didik. Pada tahap ini peserta didik di evaluasi tentang materi gerak lurus berupa lisan maupun tulisan. Tahap ini merupakan pengembangan dari pendekatan konstruktivistik.

\subsection{Media pembelajaran}

Menurut Depdiknas (Ali Muhson, 2010) istilah media berasal dari bahasa Latin yang merupakan bentuk jamak dari "medium" yang secara harafiah berarti perantara atau pengantar. Makna umumnya adalah segala sesuatu yang dapat menyalurkan informasi dari sumber informasi kepada penerima informasi. Proses belajar mengajar pada dasarnya juga merupakan proses komunikasi, sehingga media yang digunakan dalam pembelajaran disebut media pembelajaran. Media pembelajaran merupakan bagian dari sumber belajar yang merupakan kombinasi antara perangkat lunak (bahan belajar) dan perangkat keras (alat belajar).

Pemakaian media pembelajaran dalam proses belajar mengajar dapat membangkitkan minat dan keinginan yang baru, membangkitkan motivasi dan rangsangan kegiatan belajar, dan bahkan membawa pengaruh-pengaruh psikologis terhadap pebelajar. Penggunaan media pembelajaran pada tahap orientasi pengajaran akan sangat membantu keefektifan proses pembelajaran dan penyampaian pesan dan isi pelajaran pada saat itu. Menurut Wiratmojo,P dan Sasonohardjo (Iwan Falahudin, 2014).

Guna meningkatkan efektivitas dan efisiensi pembelajaran, perlu dikembangkan berbagai model pembelajaran yang kreatif dan inovatif. Hal ini perlu dilakukan agar proses pembelajaran tidak terkesan kurang menarik, monoton dan membosankan sehingga akan menghambat terjadinya transfer of knowledge. Oleh karena itu peran media dalam proses pembelajaran menjadi penting karena akan menjadikan proses pembelajaran tersebut menjadi lebih bervariasi dan tidak membosankan. (Ali Muhson, 2010).

Secara umum, manfaat media dalam proses pembelajaran adalah memperlancar interaksi antara guru dan siswa sehingga kegiatan pembelajaran akan lebih efektif dan efisien. Tetapi secara khusus ada beberapa manfaat media yang lebih rinci. Kemp dan Dayton (Ali Muhson, 2010) mengidentifikasikan beberapa manfaat media dalam pembelajaran yaitu:

1. Penyampaian materi pelajaran dapat diseragamkan.

2. Proses pembelajaran menjadi lebih jelas dan menarik

3. Proses pembelajaran menjadi lebih interaktif 
4. Efisiensi dalam waktu dan tenaga

5. Meningkatkan kualitas hasil belajar siswa

6. Media memungkinkan proses belajar dapat dilakukan di mana saja dan kapan saja

7. Media dapat menumbuhkan sikap positif siswa terhadap materi dan proses belajar

8. Mengubah peran guru ke arah yang lebih positif dan produktif.

\subsection{Macromedia flash}

Macromedia Flash atau sekarang bias kita sebut Adobe Flash adalah sebuah program khusus yang dikeluarkan Adobe untuk mendesain Animasi dua dimensi untuk keperluan berbagai hal. Contohnya membuat animasi untuk web dan sebagainya tergantung keperluan pengguna. Selain itu, sebagai pendidik juga tidak kalah ikut andil dalam penggunaan media tersebut. Animasi atau gambar bergerak adalah media yang pas sebagai media pembelajaran untuk menerangkan sesuatu yang abstrak. Banyak fitur-fitur baru dalam Flash yang dapat meningkatkan kreativitas dalam pembuatan isi media yang kaya dengan memanfaatkan kemampuan aplikasi tersebut secara maksimal. Fitur-fitur baru ini membantu kita lebih memusatkan perhatian pada desain yang dibuat secara cepat, bukannya memusatkan pada cara kerja dan penggunaan aplikasi tersebut.

\section{KESIMPULAN}

Penggunaaan aplikasi Macromedia Flash sebagai media dalam model pembelajaran POE2WE dapat membantu pemahaman siswa dalam mempelajari konsep-konsep dalam Pelajaran Fisika karena berisi Animasi yang relatif mudah dimengerti dan membuat materi pelajaran lebih menarik dan tidak monoton.

\section{REFERENSI}

Falahudin, I. (2014). Pemanfaatan Media dalam Pembelajaran. Jurnal lingkungan widjaiswara. Edisi 1 No. 4

Muhson, A. (2010). Pengembangan Media Pembelajaran Berbasis Teknologi Informasi. Jurnal pendidikan akuntansi Indonesia. Vol.VIII No.2

Nana, N. Penerapan Model Creative Problem Solving Berbasis Blog Sebagai Inovasi Pembelajaran Di Sekolah Menengah Atas Dalam Pembelajaran Fisika. In Prosiding SNFA (Seminar Nasional Fisika dan Aplikasinya) (Vol. 3, pp. 190-195).

Nana, S., Akhyar, M., \& Rochsantiningsih, D. (2014). Pengembangan Pembelajaran Fisika SMA Melalui Elaboration Write and Evaluation (EWE) dalam Kurikulum 2013. In Seminar Nasional Pendidikan Sains.

Nana, N., \& Surahman, E. Pengembangan Inovasi Pembelajaran Digital Menggunakan Model Blended POE2WE di Era Revolusi Industri 4.0. In Prosiding SNFA (Seminar Nasional Fisika dan Aplikasinya) (Vol. 4, pp. 82-90).

Periandana, VFD. \& Asto, IGP. (2015). Pengembangan Media Pembelajaran Multimedia Interaktif Berbantuan Software Macromedia Flash Pada Kompetensi Dasar Menerapkan Macammacam Gerbang Dasar Rangkaian Logika Di Smk Negeri 2 Bojonegoro. Jurnal pendidikan teknik elektro. Vol. 4 No.1

Viajayani, ER. (2013). Pengembangan Media Pembelajaran Fisika Menggunakan Macromedia Flash Pro 8 Pada Pokok Bahasan Suhu Dan Kalor. UPT perpustakaan Universitas sebelas maret. 